\title{
Contents, Vol. 31, 1975
}

\section{Index}

No.1

Vieregge, W. H. (Bonn): Kritische Stellungnahme zur Arbeit von E. Emerit:

«Nouvelle contribution à la théorie des 'locus'»

Emerit, E. (Alger): Nouvelle contribution à la théorie des «locus». 2e partie.

Réponse à Гarticle de W. H. Vieregge: « Kritische Stellungnahme zur Arbeit von

E. Emerit, 〈Nouvelle contribution à la théorie des 'locus'〉»

(A New Contribution to the "Locus" Theory: Second Part)

Kahn, M. (Ann Arbor, Mich.): Arabic Emphatics: The Evidence for Cultural De terminants of Phonetic Sex-Typing 38

Malécot, A. (Santa Barbara, Calif.): The Glottal Stop in French

Varia

64

No. 2

Gilbert, J. H. and Wyman, V. J. (Vancouver): Discrimination Learning of Nasalized and Non-Nasalized Vowels by Five-, Six-, and Seven-Year-Old Children 65

Barbon Rodriguez, J. A. (Bonn): El rehilamiento

(The 'Rehilamiento')

81

Libri

Ladefoged, P.: Preliminaries to Linguistics (H. Pilch)

No. 3-4

Liberman, A. S. (Leningrad): Stress in Icelandic. A Chapter on Scandinavian and

General Prosody

Grosjean, F. et Deschamps, A. (Paris): Analyse contrastive des variables tempo-relies de Tanglais et du français: vitesse de parole et variables composantes, phé-nomènes d'hésitation

(Contrastive Analysis of the Temporal Variables of English and French: Speech

Rate and its Determining Variables - Hesitation Phenomena) 144

LaRiviere, C. (Kansas City, Mo.): Contributions of Fundamental Frequency and

Formant Frequencies to Speaker Identification 185

Nihalani, P. (Hyderabad): Air Flow Rate in the Production of Stops in Sindhi . .

Giles, S. B. and Moll, K. L. (Iowa City, Iowa): Cinefluorographic Study of Select

ed Allophones of English/1/

Löfqvist, A. (Lund): Intrinsic and Extrinsic F0 Variations in Swedish Tonal

Accents 228

Rietveld, A. C. M. (Bonn): Untersuchungen zur Vokaldauer im Deutschen

(Experiment on the Duration of the Vowel in German)

Kong-On Kim (Los Angeles, Calif.): The Nature of Temporal Relationship between

Adjacent Segments in Spoken Korean 259

Lehfeldt, W. (Bochum): Die Verteilung der Phonemzahl in den natürlichen Spra-chen (The Distribution of the Number of Phonemes in the Natural

Languages) . . 274

Oller, D. K. and Eilers, R. E. (Seattle, Wash.): Phonetic Expectation and Tran

scription Validity 288

Libri

Philipp, M.: Phonologie de Гallemand (O. Werner)

Index autorum 312 